' Department of General Surgery, Peking Union Medical College Hospital, Chinese Academy of Medical Science \& Peking Union Medical College, Tsinghua University, Beijing 100730, China
Correspondence to: Quan Liao/Yupei Zhao Department of General Surgery Peking Union Medical College Hospital, Chinese Academy of Medical Science \& Peking Union Medical College, Tsinghua University, 1 Shuai Fu Yuan Hu Tong, 100730 - Beijing, China lqpumc@yahoo.com.cn zhao8028@263.net

Received on 12/Sept/2011 Accepted on 27/Feb/2012

\section{Mutation analysis in two Chinese families with multiple endocrine neoplasia type 1}

\author{
Análise de mutações em duas famílias chinesas \\ com neoplasia endócrina múltipla tipo 1
}

Zhang Wen', Quan Liao', Ya Hu', Yupei Zhao'

\begin{abstract}
Objective: This study aimed at identifing mutations in two Chinese genealogies with MEN1. Subjects and methods: Three members of two Chinese families with MEN1 were enrolled in this study, and all of the coding regions and adjacent sequences of the MEN1 gene were amplified and sequenced. Results: A recurrent mutation of heterozygous change T>A at IVS $4+1$ was found in family I, and a novel insGAGGTGG mutation (c.703-709dup7bp) resulted in a frameshift (p.A237Gfsx13) in family II. Conclusion: We are able to add a new mutation of MEN1 gene in Chinese patients with MEN1 that will be useful for the diagnosis and treatment of the disease. Arq Bras Endocrinol Metab. 2012;56(3):184-9
\end{abstract}

Keywords

Multiple endocrine neoplasia type 1; MEN1 gene; germline mutation; menin

\section{RESUMO}

Objetivo: O objetivo deste estudo foi identificar as mutações em duas famílias chinesas com NEM1. Sujeitos e métodos: Três membros das duas famílias chinesas foram estudados. Em todos eles, as regiões codificadoras e sequências adjacentes do gene MEN1 foram amplificadas e sequenciadas. Resultados: Uma alteração heterozigota recorrente de T>A em IVS 4+1 foi encontrada na família I, e uma nova mutação insGAGGTGG (c.703-709dup7bp) levou a um frameshift (p.A237Gfsx13) na família II. Conclusão: Adicionou-se uma nova mutação ao gene MEN1 em pacientes chineses com diagnóstico de NEM1 que vai ser útil no diagnóstico e tratamento da doença. Arq Bras Endocrinol Metab. 2012;56(3):184-9

Descritores

Neoplasia endócrina múltipla tipo 1; gene MEN1; mutação germinal

\section{INTRODUCTION}

$\mathrm{M}$ ultiple endocrine neoplasia type 1 (MENl), first reported by Wermer (1) in 1954, is an autosomal dominant disorder characterized by varying combinations of tumors involving the parathyroid $(90 \%-100 \%)$, enteropancreatic neuroendocrine tissues (30\%-75\%) and the anterior pituitary $(50 \%-65 \%)$, with penetrance higher than $90 \%$ by age $50(2,3)$. Clinical manifestations of MENl are generally related to their products of secretion and, less frequently, to their primary sites or metastasis (4). In the absence of treatment, patients with MENl die earlier (5). Nonfunctional pancreatic endocrine tumors have a much less favorable prognosis. Approximately $50 \%$ to $80 \%$ of these neoplasms recur or metastasize, and up to one third of patients already have metastases at the initial presentation (6). Nonfunctional pancreatic tumors frequently determine hepatic metastasis, while duodenal gastrinomas determine, in most cases, metastasis to local lymph nodes (5,7-9). Other tumors with lower penetrance in MENl are malignant and frequently diagnosed later on. These tumors are: neuroendocrine thymic and bronchial tumors (10), glucagonomas (11), somatostatinomas (12), and vipomas (13). The gene causing MENl is 
localized to chromosome $1 \mathrm{lq} 13$. The MENI gene consists of 10 exons that span approximately $9 \mathrm{~kb}$ of genomic DNA. MENI germline mutations can be identified in more than $85 \%$ of MENl families.

In the present study, we analyzed and identified MEN1 germline mutations in two Chinese families, supporting the practical importance of early detection and individualized surgical therapy for MENl patients.

\section{SUBJECTS AND METHODS}

\section{Clinical data}

Diagnosis of MENl was based on the presence of tumors in two or more of the three principal systems, i.e., parathyroid, anterior pituitary, and enteropancreatic neuroendocrine tissues (14). Detailed family histories were obtained from the probands and available family members. Individual tumors were classified according to clinical features.

Patient 1 of family I visited our hospital due to repeated hypoglycemic attacks and, at age 48 , she received a hypophysectomy at another hospital. She had a history of hypertension, but no definite history of hereditary disease (Figure 1). Laboratory findings for the patient upon admission are summarized in table 1. Elevated levels of serum $\mathrm{Ca}^{2+}, \mathrm{PTH}$, insulin, and gastrin, and decreased levels of blood glucose were noted. Parathyroid MIBI imaging showed right parathyroid with hyperparathyroidism (Figure 2A). CT scan of the pancreas revealed multiple nodules with partial calcification, as well as a left adrenal nodule (adenoma; Figure $2 \mathrm{~B} \sim \mathrm{F}$ ). MRI images of the skull and brain found an irregular pituitary with homogeneous signal intensity. According to these findings, the patient was then diagnosed with MENl (pancreatic tumor, hyperparathyroidism with right parathyroid tumor, left adrenal adenoma). The right parathyroid tumor was completely removed by surgery, and pathology confirmed the diagnosis of adenoma (Figure 3A). During laparotomy, ultrasonography showed one nodule in the pancreatic head (diameter: $2.5 \mathrm{~cm}$ ), and one nodule in the pancreatic tail (diameter: $1.5 \mathrm{~cm}$ ). Subsequently, these two pancreatic tumors were resected. Pathology and immunohistochemistry confirmed the diagnosis of insulinomas for two pancreatic tumors (Figure $3 \mathrm{~B} \sim \mathrm{E}$ ). No treatment for left adrenal adenoma was determined at this time, but the patient underwent regular follow-up.
Table 1. Laboratory findings in the two patients

\begin{tabular}{lccc}
\hline & $\begin{array}{c}\text { Reference } \\
\text { range }\end{array}$ & Patient 1 & Patient 2 \\
\hline Plasma glucose $(\mathrm{mmol} / \mathrm{L})$ & $3.6 \sim 6.1$ & 1.7 & 4.5 \\
Insulin $(\mu \mathrm{ll} / \mathrm{mL})$ & $2.0 \sim 16$ & 47.58 & 9.8 \\
Ca $(\mathrm{mmol} / \mathrm{L})$ & $2.13 \sim 2.70$ & 2.99 & 2.81 \\
P $(\mathrm{mmol} / \mathrm{L})$ & $0.81 \sim 1.45$ & 0.68 & 0.75 \\
PTH $(\mathrm{ng} / \mathrm{L})$ & $11 \sim 62$ & 596 & 521.7 \\
PRL $(\mathrm{ng} / \mathrm{mL})$ & $2.1 \sim 11.7$ & 7.93 & 47.6 \\
TSH $(\mu / \mathrm{l} / \mathrm{mL})$ & $0.38 \sim 4.43$ & 0.58 & 2.89 \\
Gastrin $(\mathrm{pg} / \mathrm{mL})$ & $<100$ & 180.7 & 48.9 \\
GH $(\mathrm{ng} / \mathrm{mL})$ & $<2$ & 0.1 & 2.3 \\
ACTH $(\mathrm{pg} / \mathrm{mL})$ & $0 \sim 45$ & 6.4 & 25.0 \\
\hline
\end{tabular}

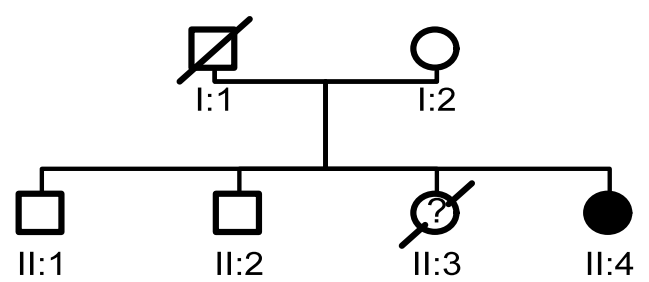

Figure 1. Genealogy chart of family I.

Patient 2 of family II visited our hospital due to recurrent diarrhea for about 4 years. At age 32 , he received a hypophysectomy and postoperative radiotherapy at another hospital. His elder brother had undergone enucleation of a pancreatic insulinoma, and resection of a parathyroid adenoma (Figure 4). Laboratory findings for the patient upon admission are summarized in table 1 . Elevated levels of serum $\mathrm{Ca}^{2+}, \mathrm{PTH}, \mathrm{PRL}$, and GH, and decreased serum phosphorous were found. Parathyroid MIBI imaging showed left parathyroid with hyperparathyroidism (Figure 5A). A nodule in the pancreatic head (size: $1.1 \mathrm{~cm} \times 1.3 \mathrm{~cm} \times 1.0 \mathrm{~cm}$ ) and a nodule in the pancreatic tail (size: $1.3 \mathrm{~cm} \mathrm{x} 3.4 \mathrm{~cm} \mathrm{x} 2.9 \mathrm{~cm}$ ) were found in the CT scan (Figure 5B F). Endoscopy found a duodenal ulcer. Given these findings, the patient was diagnosed with MEN1. Left parathyroid tumor resection was performed, and the pathology showed that the parathyroid tumor was an adenoma $(6.0 \mathrm{~cm} \times 2.0$ $\mathrm{cm}$; Figure 6A). Pancreatic head and tail tumors were removed by surgery, and pathology and immunohistochemistry showed well differentiated neuroendocrine tumors (Figure 6B K). 

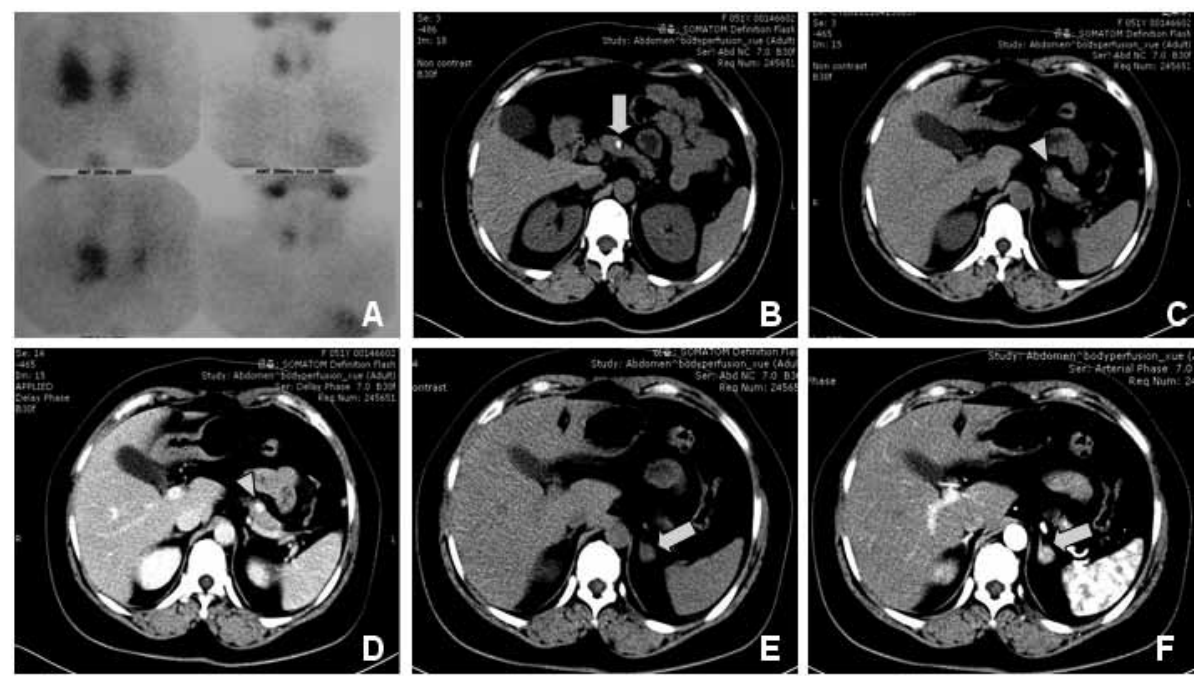

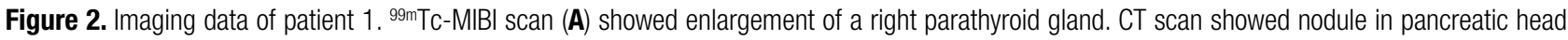
with partial calcification (B), nodule in pancreatic tail (C, D), and nodule in left adrenal (E, F).
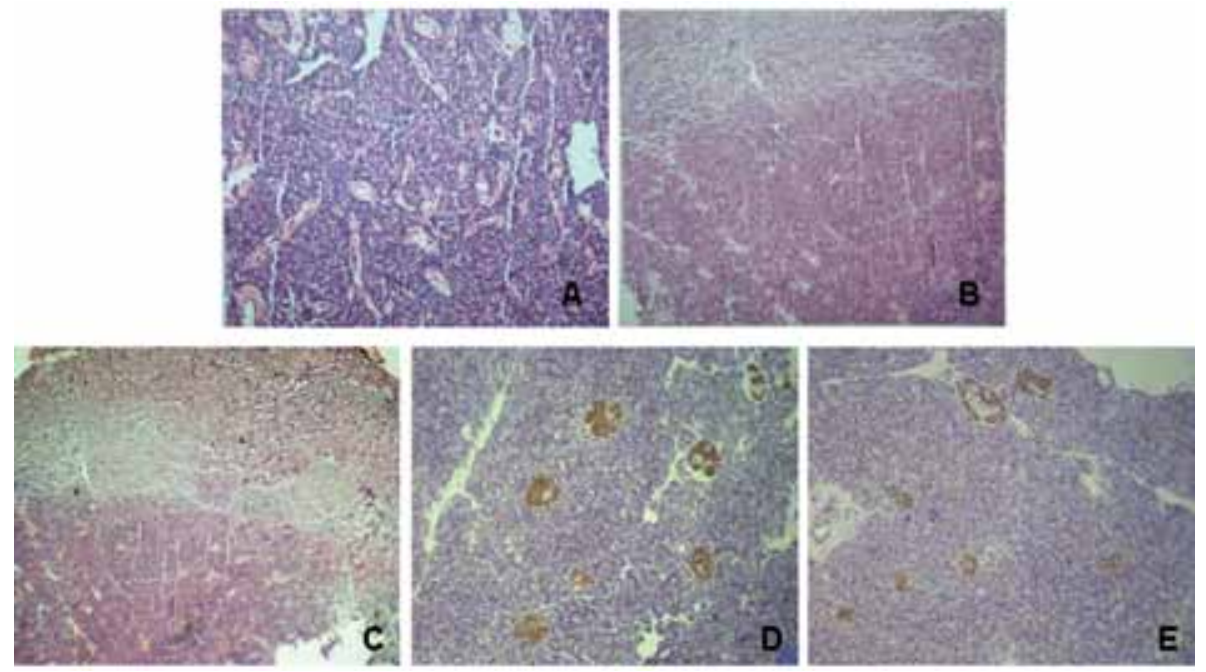

Figure 3. Histopathological section A shows parathyroid adenoma ( $\mathrm{HE}$, original magnification 100x), and sections $\mathbf{B}$, C show an insulinoma in the pancreatic head and tail, respectively (HE, original magnification 100x). Immunohistochemistry sections $\mathbf{D}$, E show positive immunohistochemical analysis for insulin of pancreatic head and tail tumor, respectively (original magnification 100x).

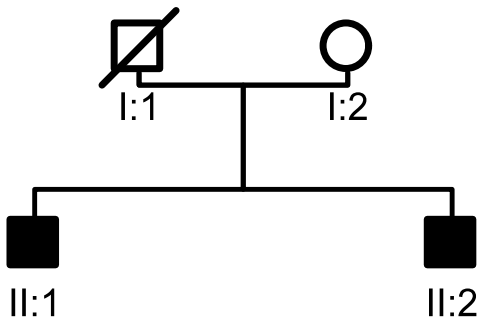

Figure 4. Genealogy chart of family II.
These two patients were diagnosed with MENl with all the characteristics of gastrointestinal neuroendocrine tumors, parathyroid adenomas, and pituitary tumors. The elder brother of the patient in family II also had history of insulinoma and parathyroid adenoma.

Participants were informed on the implications and purpose of this genetic study. A written informed consent was obtained from all patients that wanted to participate. 

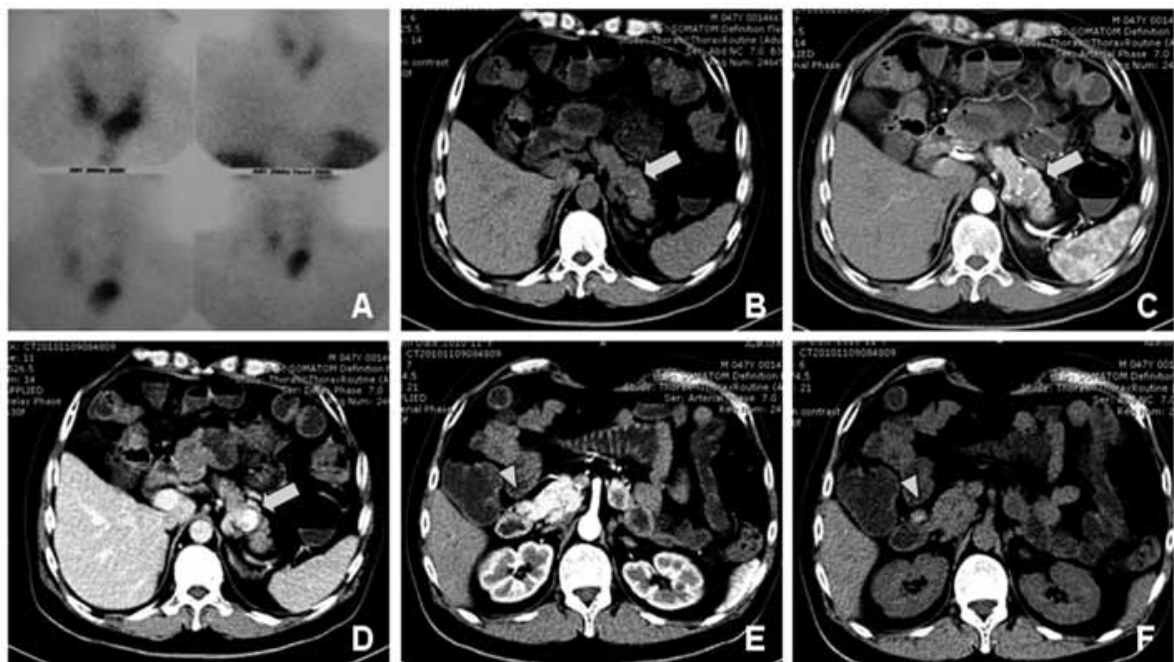

Figure 5. Imaging data of patient 2. ${ }^{99 m} \mathrm{Tc}-\mathrm{MIBI}$ scan (A) showed enlargement of left parathyroid gland. CT scan showed nodule in the pancreatic tail $(\mathbf{B}$ C, D) and a nodule in the pancreatic head (E, F).

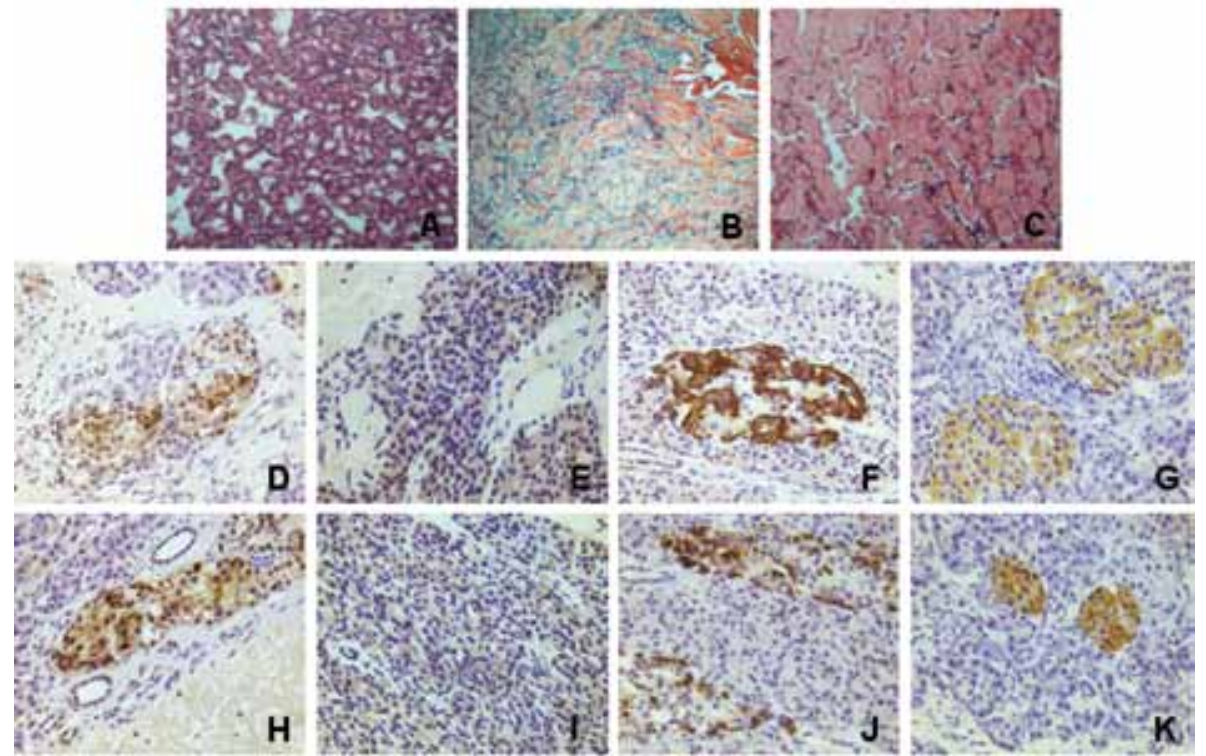

Figure 6. Histopathological section A shows parathyroid adenoma (HE, original magnification, 100x), sections B, C show well differentiated neuroendocrine tumors in the pancreatic head and tail, respectively (HE, original magnification, 100x). Immunohistochemistry sections D, E, F, G show positive immunohistochemical analysis of pancreatic head tumor for somatostatin, gastrin, glucagon, and insulin, respectively (original magnification, 400x), sections $\mathbf{H}, \mathbf{I}, \mathbf{J}, \mathbf{K}$ show positive immunohistochemical analysis of pancreatic tail tumor for somatostatin, gastrin, glucagon, and insulin, respectively (original magnification, 400x).

\section{DNA extraction and mutation screening}

Venous blood samples were obtained from three patients of two families ( 1 female and 2 males) for genetic analyses. Genomic DNA was isolated from peripheral blood. Exons were amplified by polymerase chain reaction (PCR) (15). Purified PCR products were then sequenced.

\section{RESULTS}

By direct sequencing of MENI coding region, a recurrent mutation of heterozygous change T>A at IVS $4+1$ was found in family I (Figure 7). A novel insGAGGTGG mutation (c.703-709dup7bp) resulted in a frameshift (p.A237Gfsxl3) in family II (Figure 8). 


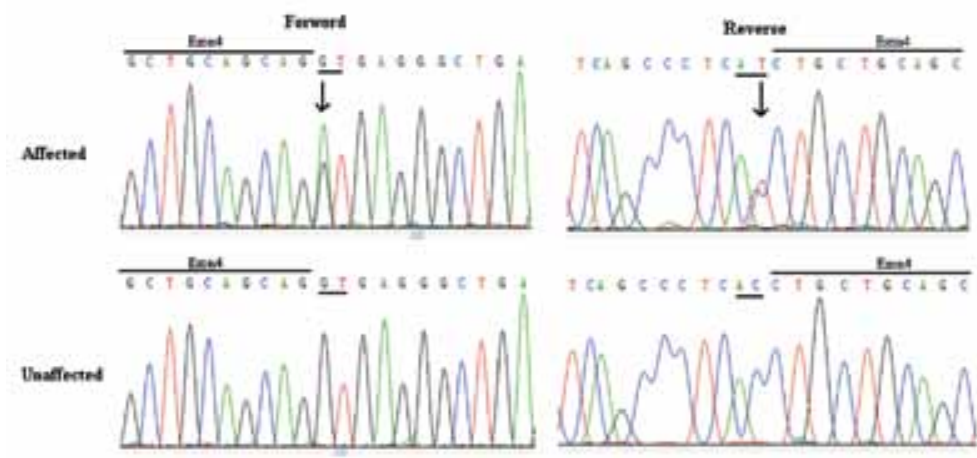

Figure 7. DNA sequence analysis of MEN1 in unaffected and affected individuals of family I. A heterozygous change T > A at IVS4+1 was noted in affected individuals.
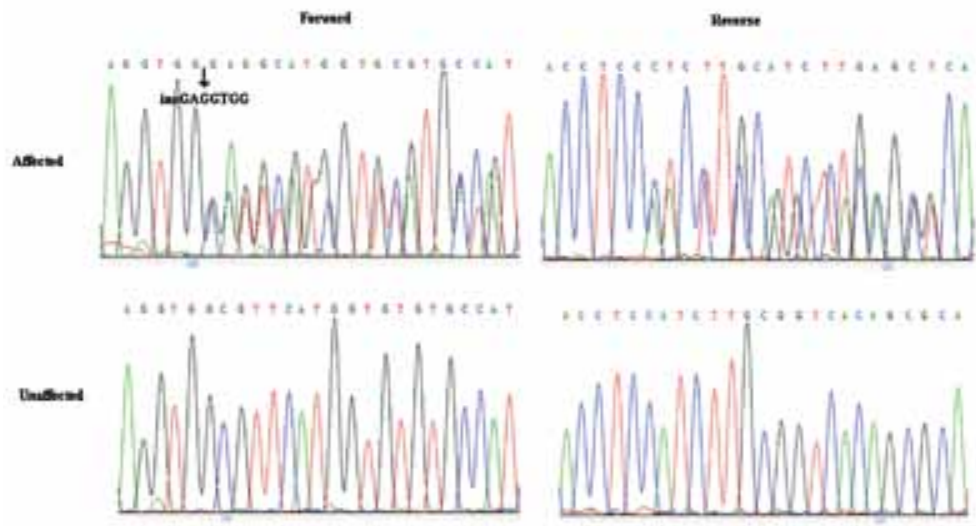

Figure 8. DNA sequence analysis of MEN1 in unaffected and affected individuals in family II. An insGAGGTGG mutation (c.703-709dup7bp) was found, resulting in a frameshift (p.A237Gfsx13).

\section{DISCUSSION}

A total of 1,336 mutations of MENI have been reported in the first decade following identification of this gene. The 1,133 germline mutations are scattered throughout the entire 1,830-bp coding region and splice sites of the MENI gene, and consist of $23 \%$ nonsense mutation, $9 \%$ splice site mutations, $41 \%$ frameshift deletions or insertions, $6 \%$ in-frame deletions or insertions, $20 \%$ missense mutation, and $1 \%$ whole or partial gene deletions (16,17). The MEN1 gene encodes a 610 -amino acid protein referred to as menin, which is ubiquitously expressed, and is predominantly a nuclear protein in nondividing cells (18). However, in dividing cells, it is mainly found in the cytoplasm (19). Menin has at least three nuclear localization signals (20).

$M E N 1$ germline mutations were identified in more than $85 \%$ of the MENl families investigated when full-length sequencing of the open reading frame was performed (21-23). Until now, some genes were recently identified as probable causes of MEN1-like condition, such as mixed lineage leukemia (MLL): $p 15, p 18, p 21$ and $p 27$ (24-27). However, the great diversity, together with widely scattered locations of the MENI mutation and a lack of genotype-phenotype correlation, make such mutational screening time consuming, laborious, and expensive $(28,29)$. Nevertheless, an integrated program of both mutational analysis, to identify mutant gene carriers, and biochemical screening, to detect the development of tumors, is advantageous and used by many centers $(14,17,30)$. Thus, a DNA test identifying an individual as a mutant gene carrier is unlikely to lead to immediate medical or surgical treatment, but to earlier and more frequent biochemical and radiologic screening, whereas a DNA result indicating that an individual is not at risk will lead to no further clinical investigation. The identification of MENI mutations may be of help in the clinical management of patients with this disorder and their families (17). Medications for 
MENl should control most features of excess of some hormones (gastrin, PRL etc.). Surgery should control features of excess of other hormones (PTH and insulin). However, surgery has not been shown to prevent or cure MENl-related cancers (14).

In conclusion, we have identified a novel insGAGGTGG mutation (c.703-709dup7bp) resulting in a frameshift (p.A237Gfsxl3) in a Chinese family. This finding extends our knowledge of the variety of genetic abnormalities associated with familial MEN1. Functional studies are necessary to evaluate and understand the impact of this insertion mutation on the clinical picture.

Disclosure: no potential conflict of interest relevant to this article was reported.

\section{REFERENCES}

1. Wermer P. Genetic aspects of adenomatosis of endocrine glands. Am J Med. 1954;16(3):363-71.

2. Trump D, Farren B, Wooding C, Pang JT, Besser GM, Buchanan $\mathrm{KD}$, et al. Clinical studies of multiple endocrine neoplasia type 1 (MEN1). QJM. 1996;89(9):653-69.

3. Skogseid B, Rastad J, Oberg K. Multiple endocrine neoplasia type 1. Clinical features and screening. Endocrinol Metab Clin North Am. 1994;23(1):1-18.

4. Thakker RV. Multiple endocrine neoplasia type 1 (MEN1). Best Pract Res Clin Endocrinol Metab. 2010;24(3):355-70.

5. Dean PG, van Heerden JA, Farley DR, Thompson GB, Grant CS, Harmsen WS, et al. Are patients with multiple endocrine neoplasia type I prone to premature death? World J Surg. 2000;24(11):1437-41.

6. Arnold R. Endocrine tumours of the gastrointestinal tract. Introduction: definition, historical aspects, classification, staging, prognosis and therapeutic options. Best Pract Res Clin Gastroenterol. 2005;19(4):491-505.

7. Norton JA, Kivlen M, Li M, Schneider D, ChuterT, Jensen RT. Morbidity and mortality of aggressive resection in patients with advanced neuroendocrine tumors. Arch Surg. 2003;138(8):859-66.

8. Shepherd JJ, Challis DR, Davies PF, McArdle JP, Teh BT, Wilkinson S. Multiple endocrine neoplasm, type 1. Gastrinomas, pancreatic neoplasms, microcarcinoids, the Zollinger-Ellison syndrome, lymph nodes, and hepatic metastases. Arch Surg. 1993;128(10):1133-42.

9. Fendrich $V$, Langer $P$, Celik I, Bartsch DK, Zielke A, Ramaswamy A, et al. An aggressive surgical approach leads to long-term survival in patients with pancreatic endocrine tumors. Ann Surg. 2006;244(6):845-51; discussion 852-43.

10. Abe T, Sato M, Okumura T, Shioyama $Y$, Kiyoshima M, Asato $Y$, et al. FDG PET/CT findings of thymic carcinoid and bronchial carcinoid in a patient with multiple neuroendocrine neoplasia type 1. Clin Nucl Med. 2008;33(11):778-9.

11. Grama D, Eriksson B, Martensson H, Cedermark B, Ahren B, Kristoffersson $A$, et al. Clinical characteristics, treatment and survival in patients with pancreatic tumors causing hormonal syndromes. World J Surg. 1992;16(4):632-9.

12. Garbrecht N, Anlauf M, Schmitt A, Henopp T, Sipos B, Raffel A, et al. Somatostatin-producing neuroendocrine tumors of the duodenum and pancreas: incidence, types, biological behavior, asso- ciation with inherited syndromes, and functional activity. Endocr Relat Cancer. 2008;15(1):229-41.

13. Goudet P, Murat A, Binquet C, Cardot-Bauters C, Costa A, Ruszniewski $P$, et al. Risk factors and causes of death in MEN1 disease. A GTE (Groupe d'Etude des Tumeurs Endocrines) cohort study among 758 patients. World J Surg. 2010;34(2):249-55.

14. Brandi ML, Gagel RF, Angeli A, Bilezikian JP, Beck-Peccoz P, Bordi $C$, et al. Guidelines for diagnosis and therapy of MEN type 1 and type 2. J Clin Endocrinol Metab. 2001;86(12):5658-71.

15. Hai N, Aoki N, Matsuda A, Mori T, Kosugi S. Germline MEN1 mutations in sixteen Japanese families with multiple endocrine neoplasia type 1 (MEN1). Eur J Endocrinol. 1999;141(5):475-80.

16. Chandrasekharappa SC, Guru SC, Manickam P, Olufemi SE, Collins FS, Emmert-Buck MR, et al. Positional cloning of the gene for multiple endocrine neoplasia-type 1. Science. 1997;276(5311):404-7.

17. Lemos MC, Thakker RV. Multiple endocrine neoplasia type 1 (MEN1): analysis of 1336 mutations reported in the first decade following identification of the gene. Hum Mutat. 2008;29(1):22-32.

18. Guru SC, Goldsmith PK, Burns AL, Marx SJ, Spiegel AM, Collins FS, et al. Menin, the product of the MEN1 gene, is a nuclear protein. Proc Natl Acad Sci U S A. 1998;95(4):1630-4.

19. Huang SC, Zhuang Z, Weil RJ, Pack S, Wang C, Krutzsch HC, et al. Nuclear/cytoplasmic localization of the multiple endocrine neoplasia type 1 gene product, menin. Lab Invest. 1999;79(3):301-10.

20. La P, Desmond A, Hou Z, Silva AC, Schnepp RW, Hua X. Tumor suppressor menin: the essential role of nuclear localization signal domains in coordinating gene expression. Oncogene. 2006;25(25):3537-46.

21. Agarwal SK, Kester MB, Debelenko LV, Heppner C, Emmert-Buck MR, Skarulis MC, et al. Germline mutations of the MEN1 gene in familial multiple endocrine neoplasia type 1 and related states. Hum Mol Genet. 1997;6(7):1169-75.

22. Bassett JH, Forbes SA, Pannett AA, Lloyd SE, Christie PT, Wooding $C$, et al. Characterization of mutations in patients with multiple endocrine neoplasia type 1. Am J Hum Genet. 1998;62(2):232-44.

23. Poncin J, Abs R, Velkeniers B, Bonduelle M, Abramowicz M, Legros $\mathrm{JJ}$, et al. Mutation analysis of the MEN1 gene in Belgian patients with multiple endocrine neoplasia type 1 and related diseases. Hum Mutat. 1999;13(1):54-60.

24. Taguchi R, Yamada M, Horiguchi K, Ozawa A, Shibusawa N, Hashimoto $\mathrm{K}$, et al. Haploinsufficient and predominant expression of multiple endocrine neoplasia type 1 (MEN1)-related genes, MLL, p27(Kip1) and p18(Ink4C) in endocrine organs. Biochem Biophys Res Commun. 2011;415(2):378-83.

25. Agarwal SK, Mateo CM, Marx SJ. Rare germline mutations in cyclin-dependent kinase inhibitor genes in multiple endocrine neoplasia type 1 and related states. J Clin Endocrinol Metab. 2009;94(5):1826-34.

26. Ishida E, Yamada M, Horiguchi K, Taguchi R, Ozawa A, Shibusawa $\mathrm{N}$, et al. Attenuated expression of menin and p27 (Kip1) in an aggressive case of multiple endocrine neoplasia type 1 (MEN1) associated with an atypical prolactinoma and a malignant pancreatic endocrine tumor. Endocr J. 2011;58(4):287-96.

27. Georgitsi M, Raitila A, Karhu A, van der Luijt RB, Aalfs CM, SaneT, et al. Germline CDKN1B/p27Kip1 mutation in multiple endocrine neoplasia. J Clin Endocrinol Metab. 2007;92(8):3321-5.

28. Pannett AA, Thakker RV. Multiple endocrine neoplasia type 1. Endocr Relat Cancer. 1999;6(4):449-73.

29. Thakker RV. Multiple endocrine neoplasia--syndromes of the twentieth century. J Clin Endocrinol Metab. 1998;83(8):2617-20.

30. Marini F, Falchetti A, Del Monte F, Carbonell Sala S, Gozzini A, Luzi $E$, et al. Multiple endocrine neoplasia type 1. Orphanet J Rare Dis. 2006:1:38. 